\title{
Acute toxicity of the synthetic pyrethroid alpha-cypermethrin on the tadpoles of variable green toad, Bufotes variabilis (Amphibia:Anura)
}

\section{Sentetik piretroit alfa-sipermetrinin değişken desenli gece kurbağası, Bufotes variabilis iribaşlarındaki akut toksisitesi (Amphibia: Anura)}

\author{
Mert Gürkan • Seda Serbest S Sibel Hayretdağ \\ Department of Biology, Zoology Section, Faculty of Arts and Sciences, Çanakkale Onsekiz Mart University, Çanakkale, Turkey \\ ${ }^{*}$ Corresponding author: sibelhayretdag@gmail.com
}

Received date: 04.08 .2016

Accepted date: 24.10 .2016

How to cite this paper:

Gürkan, M., Serbest, S. \& Hayretdağ, S. (2016). Acute toxicity of the synthetic pyrethroid alpha-cypermethrin on the tadpoles of variable green toad, Bufotes variabilis (Amphibia:Anura). Ege Journal of Fisheries and Aquatic Sciences, 33(4): 367-371. doi: 10.12714/egejfas.2016.33.4.10

\begin{abstract}
In this study, acute toxic effects of alpha-cypermethrin were investigated in the tadpoles of Bufotes variabilis (Pallas, 1769). Tadpoles at Gosner stage 19 were exposed to $0,0.1,5$ and $10 \mu \mathrm{gl}-1$ of alpha-cypermethrin concentrations for 96 hours. Mortality, the changes in some morphological measurements (snoutvent length, body width, tail length, and wet weight), morphological anomalies and behavioral changes were evaluated at the end of the experiment. The 96 hours LC50 value was calculated as $15.62 \mu \mathrm{gl}-1$. Such morphological changes as axial anomaly, visceral edema, deformation of the mouth, and tail deformation were observed in $83 \%$ and $95 \%$ of the tadpoles in the groups treated with 5 and $10 \mu \mathrm{gl}-1$ of alpha-cypermethrin. Behavioral changes such as shortening of the swimming distance and immobility were recorded in all tadpoles exposed to alpha-cypermethrin. When all findings were evaluated totally, it was concluded that alphacypermethrin had negative effects on the development of the tadpoles of $B$. variabilis
\end{abstract}

Keywords: Bufotes variabilis, tadpole, pyrethroid, alpha-cypermethrin, anomalies

Öz: Bu çalışmada, Bufotes variabilis (Pallas, 1769) iribaşları üzerinde alfa-sipermetrinin akut toksik etkileri araşııııılı. Gosner 19. evredeki iribaşlar, 96 saat süreyle $0 ; 0,1 ; 5$ ve $10 \mu \mathrm{gl}-1$ konsantrasyonlarda alfa-sipermetrine maruz bırakııldı. Çalışma sonunda; mortalite, bazı morfolojik ölçümlerdeki değişiklikler (burun-anüs açıkığı arası uzunluğu, vücut genişliği, kuyruk uzunluğu ve ıslak ağırlık), morfolojik anomaliler ve davranışsal değişiklikler değerlendirildi. 96 saatlik LC50 değeri 15,62 ugl-1 olarak hesaplandı. 5 ve $10 \mu \mathrm{gl}-1$ alfa-sipermetrin uygulaması yapılan iribaşların, \%83 ve \%95'inde aksiyal anomali, viseral ödem, ağız deformasyonu ve kuyruk deformasyonu gibi bazı morfolojik değişiklikler gözlendi. Alfa-sipermetrin uygulaması yapılan tüm iribaşlarda yüzme mesafesinde kısalma ve dengesizlik gibi davranışsal değişiklikler kaydedildi. Tüm bulgular birlikte değerlendirildiğinde, alfa-sipermetrinin, $B$. variabilis iribaşlarının gelişimi üzerine olumsuz etkileri olduğu sonucuna ulaşıldı.

Anahtar kelimeler: Bufotes variabilis, iribaş, piretroit, alfa-sipermetrin, anomaliler

\section{INTRODUCTION}

The use of pesticides in Turkey started with DDT (dichlorodiphenyl-trichloroethane) in the 1960s and increased in time, and its amount has reached 30 thousand tons per year (Durmuşoğlu et al., 2010). In Turkey, $47 \%$ of the pesticides used are insecticides (Turabi, 2007). Because these chemicals (organochlorinated and organophosphorous) ultimately remained inadequate in pest control, first pyrethroids and then neonicotinoids were produced as alternatives (Kovganko and Kashkan, 2004). Pyrethroids are structural derivatives of the natural pyrethrins obtained from Chrysanthemum cinerariaefolium (Casida, 1980). The pyrethroids with the same effect on the sodium channels in the nervous system are divided into two as Types I and II. However, those in Type II, in which alpha-cypermethrin is also included, keep these channels open for a longer period (Kakko, 2004). Alpha- cypermethrin is effective when it is taken by contact and orally. As a result of intoxication, conduction of nerve impulses is inhibited and a fast death takes place. Alpha-cypermethrin is used in pest control in animal husbandry (in ectoparasite control), agriculture, and public health. It is one of the four cis isomers of cypermethrin and about 3-4 times more toxic than (IPCS, 1992; WHO, 2006). Due to the effect of alphacypermethrin on the sodium channels, its neurotoxic effects on mammals have been investigated in the majority of the studies carried out so far (Luty et al., 1998; Luty et al., 2000; Yu-Tao et al., 2009). Some fish species have been used to investigate toxicological effects of alpha-cypermethrin (Yılmaz et al., 2004; Sarıkaya, 2009). Rather few studies on the toxicity of alphacypermethrin in amphibians have been encountered (Greulich and Pflugmacher, 2003; Yu et al., 2013). In addition, the 
literature contains no study in which the toxic effects of alphacypermethrin on the tadpoles of $B$. variabilis are investigated.

A rapid change in ecological systems is observed as a result of the human activities which have intensified in the recent years. Especially the pesticides used in agricultural activities damage natural habitats and the chemical pollution occurring under the anthropogenic impact is observed. The effects of pesticides on organisms evidently appear in aquatic ecosystems (Ginebrada et al., 2014). When risk assessment is performed, it is seen that amphibians are more threatened than other aquatic vertebrates (Tyler, 1998). The use of shallow and seasonal puddles generally nearby agricultural lands for spawning by amphibians is the most important reason why this risk is greater (Collins and Storfer, 2003). Furthermore, the small bodies, sensitive and permeable skin and limited activity capacities of the amphibians which spend their embryonic and larval periods completely in water also increase their sensitivity to the pollutants in the environment (Wells, 2007). The specimens of $\quad$ B. variabilis are distributed in the Anatolian part of Turkey (Stöck et al., 2006). According to the IUCN (2015) criteria, they are in the "Data Deficient" category.

This study aims to determine the morphological and behavioral changes likely to occur after the administration of alpha-cypermethrin to the tadpoles of $B$. variabilis at stage 19 for 96 hours and to calculate the lethal concentration ( $L C_{10}$, $\mathrm{LC}_{50}$, and $\mathrm{LC}_{90}$ ) values.

\section{MATERIAL AND METHODS}

The tadpoles of $B$. variabilis were obtained under laboratory conditions from the adult individuals collected in amplexus from nature. The adult frog samples were collected at Çanakkale, Turkey (35 S 452284 E, 4444377 N). After the fertilisation and the fertilised eggs were divided into four equal parts. The tadpoles were housed in glass aquaria with dimensions of $350 \times 350 \times 250 \mathrm{~mm}$ and filled with rested tap water at a depth of $100 \mathrm{~mm}$. B. variabilis tadpoles at stage 19 were used in the experiment (Gosner, 1960). Each application group was composed of 20 randomly selected tadpoles. The study was performed with three replications. At the early developmental stages, the tadpoles were fed first on plant-based fish feed and then on boiled spinach and lettuce. Feeding the tadpoles had been continued until 24 hours before the application. The tadpoles were not fed during the application for not to change the environmental conditions (OECD, 2008). During the experiment, temperature $\left({ }^{\circ} \mathrm{C}\right), \mathrm{pH}$ and dissolved oxygen (mgl1) values were measured by using an Orion ecological kit. The tadpoles were housed under 14:10 photoperiod. The nutrient wastes, feces and dead tadpoles in the aquaria were removed in daily periods. Alpha-cypermethrin (CAS NO. 67375-30-8) HEKTAS with $97 \%$ purity was used as a toxic substance in the study. For the stock solution, alpha-cypermethrin was dissolved in acetone and prepared in fresh form. The stock solution was diluted to obtain the application concentrations $(0.1,5$, and 10 $\mu \mathrm{gl}-1)$. The snout-vent length $(\mathrm{mm})$, tail length $(\mathrm{mm})$, body width $(\mathrm{mm})$ and wet weight $(\mathrm{g})$ values of the tadpoles were measured both before and after the application. The wet weight (WW) values were measured by means of a scale sensitive to $0.0001 \mathrm{~g}$. A digital compass sensitive to $0.01 \mathrm{~mm}$ was used to measure snout-vent length (SVL), tail length (TL), and body width (BW). Moreover, the behavioral changes seen such as swimming distance, immobility, balance and reaction to a stimulus in the tadpoles during the application were recorded. For these purpose we selected ten tadpoles from each control and treatment group randomly. After stimulation, the swimming distance of the tadpoles per group (average distance $=5 \mathrm{~cm}$ ) was recorded with a cronometer. Then these records were analyzed. Following the exposure of alpha-cypermethrin to the tadpoles of $B$. variabilis for 96 hours, the Probit analysis was used to calculate the $\mathrm{LC}_{10}, \mathrm{LC}_{50}$, and $\mathrm{LC}_{90}$ values. The lethal concentration values were calculated at $95 \%$ confidence interval. In addition, a one-way analysis of variance (ANOVA) was used to compare the morphological measurements among the groups.

\section{RESULTS}

The mean temperature $\left({ }^{\circ} \mathrm{C}\right), \mathrm{pH}$ and dissolved oxygen $(\mathrm{mg} / \mathrm{l})$ values measured after the exposure of the tadpoles of $B$. variabilis to alpha-cypermethrin for 96 hours are presented in Table 1.

Table 1. The mean temperature, $\mathrm{pH}$ and dissolved oxygen values of each concentration in the acute toxicity tests of alpha-cypermethrin on B. variabilis

\begin{tabular}{lccc}
\hline $\begin{array}{l}\text { Alpha- } \\
\text { cypermethrin } \\
\begin{array}{l}\text { Concentrations } \\
\left(\boldsymbol{\mu} \mathrm{gl}^{-1}\right)\end{array}\end{array}$ & $\begin{array}{c}\text { Temperature } \\
\left({ }^{\circ} \mathrm{C}\right)\end{array}$ & $\mathrm{Ph}$ & $\begin{array}{c}\text { Dissolved } \\
\text { Oxygen }\left(\mathrm{mgl}^{-1}\right)\end{array}$ \\
\hline 0 (Control) & 21.2 & 7.9 & 8.4 \\
0 (Acetone-control) & 21.0 & 7.7 & 8.0 \\
0.1 & 20.8 & 7.7 & 8.1 \\
5 & 21.4 & 8.0 & 7.9 \\
10 & 20.9 & 7.7 & 8.0 \\
\hline
\end{tabular}

At the end of the application, the highest mortality rate (40\%) was detected in the group treated with $10 \mu \mathrm{gl}-1$ of alphacypermethrin. As a result of exposure to alpha-cypermethrin for 96 hours, the LC50 in the tadpoles of $B$. variabilis was calculated as $15.62 \mu \mathrm{gl}-1$ (Table 2).

Table 2. Lethal concentration values in the tadpoles of $B$. variabilis exposed to alpha-cypermethrin

\begin{tabular}{ccccc}
\hline Species & Gosner & \multicolumn{3}{c}{ Lethal concentrations $\left(\boldsymbol{\mu g l} \mathrm{I}^{-1}\right) \mathbf{9 5 \%} \mathrm{Cl}$} \\
\cline { 3 - 5 } & Stage & \multicolumn{3}{c}{96 hours } \\
\hline \multirow{3}{*}{ B. } & & $\mathrm{LC}_{10}$ & $\mathrm{LC}_{50}$ & $\mathrm{LC}_{90}$ \\
\cline { 3 - 5 } variabilis & \multirow{2}{*}{19} & 2.74 & 15.62 & $89.02(52.25-$ \\
& & $(1.69-$ & $(12.73-$ & $120.50)$ \\
& & $3.75)$ & $17.62)$ & \\
\hline
\end{tabular}

Some morphological measurements (SVL, BW, TL, and WW) at the beginning of the experiment is presented in Figure 1 , and at the end of the experiment is presented in Figure 2. 


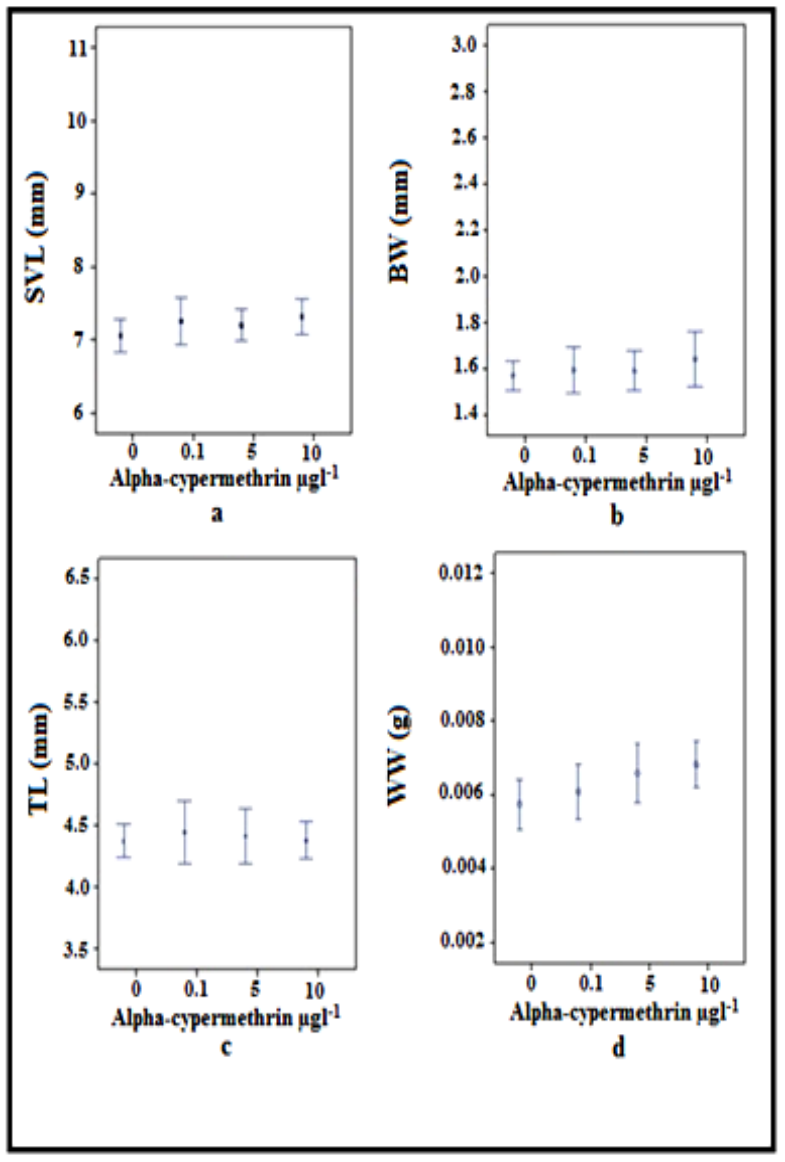

Figure 1. Morphological measurements (At the beginning of the experiment), a. SVL (snout-vent length) (mm), b. BW (body width) (mm), c. TL (tail length) (mm), and d. WW (wet weight) (g)

At the end of the experiment, SVL, BW, TL, and WW parameters was found to be significantly different between control and exposure groups $(P<0.05)$. SVL, BW, TL, and WW values of the groups and the differences among the groups after the administration of alpha-cypermethrin are presented in Table 3.
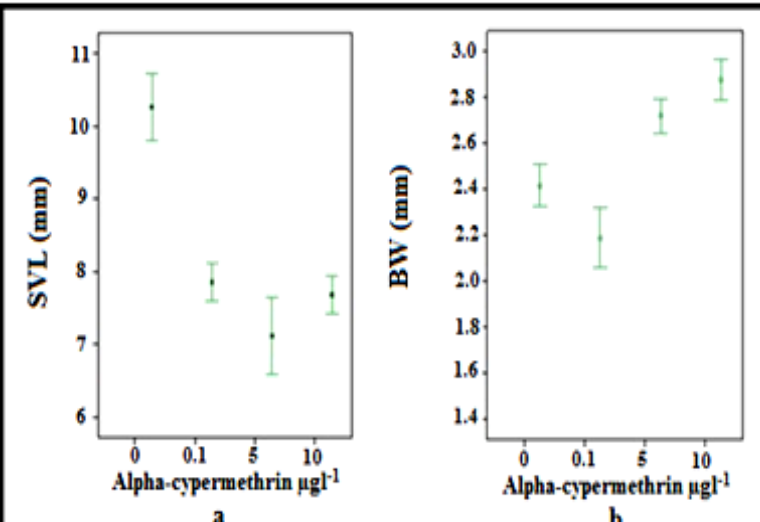

a
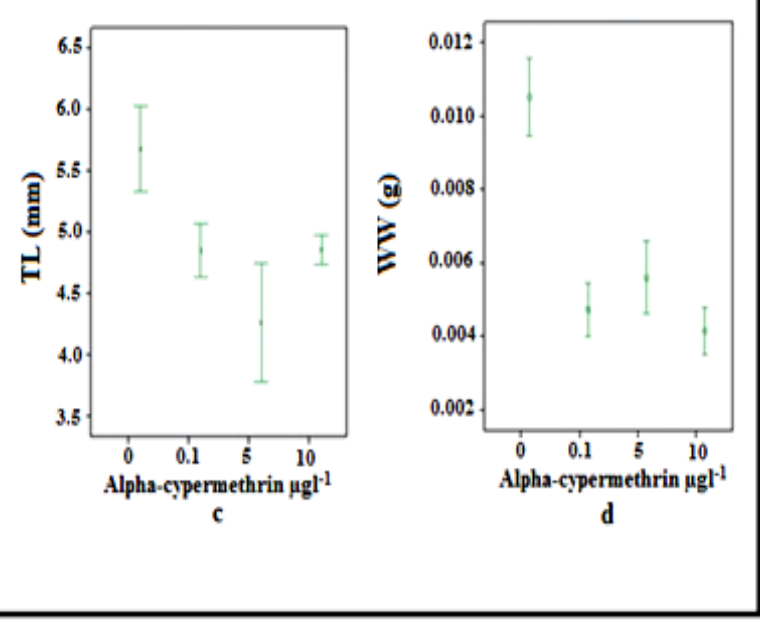

Figure 2. Morphological measurements (At the end of the experiment), a. SVL (snout-vent length) (mm), b. BW (body width) (mm), c. TL (tail length) (mm), and d. WW (wet weight) (g)

The behavioral changes supposed to have resulted from the sublethal effects of alpha-cypermethrin at the end of the study are presented in Table 4.

The behavioral changes concerned were observed to have become evident at the increasing application concentrations

Table 3. The mean values of some morphological measurements

\begin{tabular}{lllll}
\hline $\begin{array}{l}\text { Alpha-cypermethrin } \\
\text { concentrations }\left(\left.\boldsymbol{\mu g}\right|^{-1}\right)(\mathbf{n}=20)\end{array}$ & $\begin{array}{l}\text { SVL } \\
(\mathbf{m m})\end{array}$ & $\begin{array}{l}\text { BW } \\
(\mathbf{m m})\end{array}$ & $\begin{array}{l}\text { TL } \\
(\mathbf{m m})\end{array}$ & $\begin{array}{l}\text { WW } \\
(\mathbf{g})\end{array}$ \\
\hline 0 (control) & $10.31 \pm 0.22$ & $2.42 \pm 0.04$ & $5.69 \pm 0.74$ & $0.010 \pm 0.002$ \\
0 (Acetone-control) & $10.35 \pm 0.19$ & $2.30 \pm 0.05$ & $5.75 \pm 0.58$ & $0.012 \pm 0.001$ \\
0.1 & $7.90 \pm 0.11^{\mathrm{a}}$ & $2.19 \pm 0.05^{\mathrm{a}}$ & $4.87 \pm 0.30^{\mathrm{a}}$ & $0.004 \pm 0.001^{\mathrm{a}}$ \\
5 & $7.17 \pm 0.23^{\mathrm{a}}$ & $2.72 \pm 0.03^{\mathrm{b}}$ & $4.27 \pm 0.67^{\mathrm{a}}$ & $0.005 \pm 0.001^{\mathrm{a}}$ \\
10 & $7.73 \pm 0.11^{\mathrm{a}}$ & $2.88 \pm 0.04^{\mathrm{b}}$ & $4.87 \pm 0.16^{\mathrm{a}}$ & $0.004 \pm 0.001^{\mathrm{a}}$ \\
\hline
\end{tabular}

${ }^{*}$ Groups labeled with different letters are significantly different $(P<0.05)$ 
Table 4. The behavioral changes observed in the tadpoles depending on pesticide exposure.

\begin{tabular}{|c|c|}
\hline $\begin{array}{l}\text { Alpha-cypermethrin } \\
\text { Concentrations }\left(\mu \mathrm{gl}^{-1}\right) \\
(\mathrm{n}=20)\end{array}$ & Behavioral Changes \\
\hline 0 (control) & No change was recorded \\
\hline 0 (Acetone-control) & No change was recorded \\
\hline 0.1 & Shortening of the swimming distance and immobility \\
\hline 5 & Shortening of the swimming distance, immobility, and subsidence \\
\hline 10 & Shortening of the swimming distance, immobility, a late reaction to a stimulus, and subsidence \\
\hline
\end{tabular}

No significant morphological anomaly was encountered in the tadpoles of the control groups. However, obvious morphological anomalies were observed in $60 \%, 83 \%$, and $95 \%$ of the tadpoles treated with $0.1,5$, and $10 \mu \mathrm{gl}-1$ of alphacypermethrin, respectively. The visceral edema in the bodies of the tadpoles was observed to have become evident at the increasing doses of alpha-cypermethrin (Figure 3).

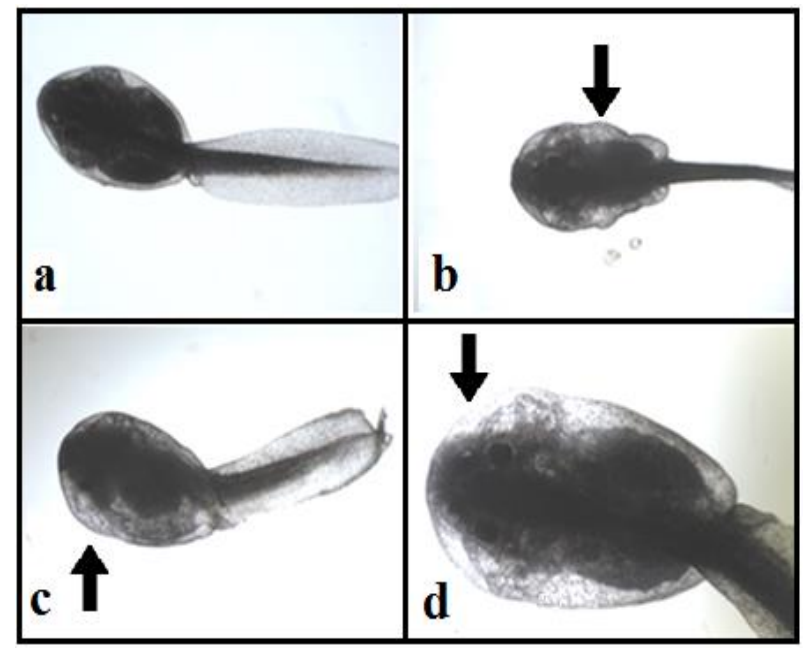

Figure 3. Overall appearances of the tadpoles at the end of the study a. $0 \mu \mathrm{gl}-1$ (control), b. $0.1 \mu \mathrm{gl}-1$, c. $5 \mu \mathrm{gl}-1$, and d. $10 \mu \mathrm{gl}-1$ of alphacypermethrin (visceral edema is shown with arrows)

It was determined that axial deformations had become evident and the tail had been deformed in the tadpoles treated with $10 \mu \mathrm{gl}-1$ of alpha-cypermethrin (Figure 4).

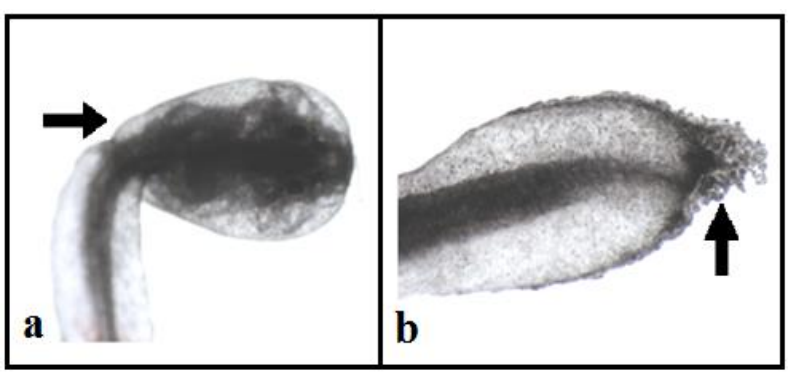

Figure 4. The morphological changes in the tadpoles treated with 10 $\mu \mathrm{gl}-1$ of alpha-cypermethrin a. Axial anomaly (shown with an arrow), b. Tail deformation (shown with an arrow)
Anomalies were detected at the mouth of the digestive tract (Figure 5) and in the eyes of the tadpoles treated with 5 and 10 $\mu \mathrm{gl}-1$ of alpha-cypermethrin.

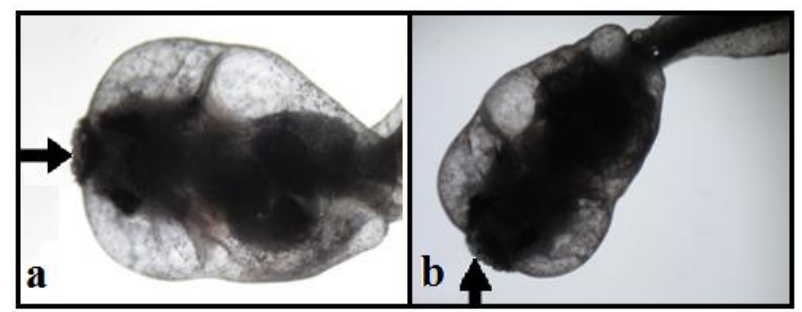

Figure 5. The mouth of the digestive tract in the tadpoles treated with a. $5 \mu \mathrm{gl}-1$, and b. $10 \mu \mathrm{gl}-1$ of alpha-cypermethrin (shown with an arrow)

\section{DISCUSSION}

As amphibians are living organisms which spend their larval periods in water, they can be seriously affected by the chemical pollutants in the environment. Morphological anomalies (visceral edema, axial anomaly, and tail deformation), a delay in the duration of larval development and an increase in the mortality rate can be observed in these living organisms, which are exposed to chemical pollution. Studies in which the effects of Type II pyrethroids on aquatic living organisms were investigated have been encountered in the literature (Bradbury and Coats, 1989; Golow and Godzi, 1994; Polat et al., 2002; Saha and Khaviraj, 2008). Synthetic pyrethroids are reported to be rather toxic for aquatic arthropods and fish (Solomon, et al., 2001). In a study carried out with the larvae of Rana arvalis, exposure of the larvae at different stages to alpha-cypermethrin was reported to have led to negative cases such as a reduction in the breeding success and a delay in the duration of metamorphosis (Greulich and Pflugmacher, 2003). Findings from the literature which were similar to those of the research concerned were determined in our study as well. Additionally, alpha-cypermethrin exposure at increasing concentrations was found to have caused morphological and behavioral changes (shortening of the swimming distance, immobility, a late reaction to a stimulus), and subsidence and an increase in the number of mortalities.

The $\mathrm{LC}_{50}$ value calculated after the exposure to alphacypermethrin for 96 hours is reported to be $6.9 \mu \mathrm{gl}-1$ in the embryos of Xenopus laevis (Yu et al., 2013). Following the 
exposure to cypermethrin-one of the B Type II pyrethroids for 96 hours, the $\mathrm{LC}_{50}$ values were calculated to be $0.4 \mu \mathrm{gl}-1$ in Scardininus erythrophthalmus, $1.2 \mu \mathrm{g} / \mathrm{l}$ in Phoxinus phoxinus, and $2.8 \mu \mathrm{gl}-1$ in Oncorhynchus mykiss, respectively (Bradbury and Coats, 1989). The value concerned was $6.5 \mu \mathrm{gl}-1$ in Rana temporaria and $9 \mu \mathrm{g} / \mathrm{l}$ in toads (Paulov, 1990). The LC 50 value of alpha-cypermethrin is $5.99 \mu \mathrm{gl}-1$ in the Oreochromis niloticus at 96 hours (Sarıkaya, 2009), whereas LC Lo $_{5}$ is $9.43 \mu \mathrm{gl}-1$ in Poecilia reticulata at 96 hours, $20 \mu \mathrm{gl}-1$ in Barbonymus

\section{REFERENCES}

Bradbury, S.P. \& Coats, J.R. (1989). Comparative toxicology of the pyrethroid insecticides. In: Editor Ware, G. W. Reviews of Environmental Contamination and Toxicology, New York: Springer, 133-177. doi: 10.1007/978-1-4613-8850-0_4

Casida, J.E. (1980). Pyrethrum flowers and pyrethroid insecticides. Environmental Health Perspectives, 34: 189-202.

Collins, J.P. \& Storfer, A. (2003). Global amphibian declines: sorting the hypotheses. Diversity and Distributions, 9: 89-98. doi: 10.1046/j.1472-4642.2003.00012.x

Durmuşoğlu, E., Tiryaki, O. \& Canhilal, R. (2010). Pesticide usage in Turkey, ruins and durability issues (In Turkish). Paper presented at: Seventh Turkey Agricultural Engineering Technical Conference, 11-15 January, Ankara, Turkey.

Ginebreda, A., Kuzmanovic, M., Guasch, H., Lopez de Alda, M., Lopez-Doval J.C., Munoz, I., Ricart, M., Romani, A.M., Sabater, S. \& Barcelo, D. (2014). Assessment of multi-chemical pollution in aquatic ecosystems using toxic units: Compound prioritization, mixture characterization and relationships with biological descriptors. Science of the Total Environment, 468: 715723. doi:10.1016/j.scitotenv.2013.08.086

Golow, A.A. \& Godzi, T.A. (1994). Acute toxicity of deltamethrin and dieldrin to Oreochromis niloticus. Bulletin of Environmental Contamination and Toxicology, 52: 351-354. doi: 10.1007/BF00197820

Gosner, K.L. (1960). A simplified table for staging anuran embryos and larvae with notes on identification. Herpetologica, 16: 183-190

Grayson, B.T., Green, M.B. \& Copping, L.G. (1990). Pest management. Paper presented at: Rice Conference, London, 455-464.

Greulich, K. \& Pflugmacher, S. (2003). Differences in susceptibility of various life stages of amphibians to pesticide exposure. Aquatic Toxicology, 65 329-336. doi:10.1016/S0166-445X(03)00153-X

IPCS (1992). Alpha-cypermethrin. Environmental health criteria. International Programme on Chemical Safety. Geneva, No:142.

IUCN (2015). Bufotes variabilis. The IUCN Red List of Threatened Species 2015: International Union for Conservation of Nature, $9 \mathrm{pp}$. doi: 10.2305/IUCN.UK.2015-1

Kakko, I. (2004). Toxic mechanisms of pyrethroids studied in vitro (Academic Dissertation). Finland: Faculty of Medicine of the University of Tampere. ISBN: 951-44-6004-9. 55 pp.

Kovganko, N.V. \& Kashkan, Z.N. (2004). Advances in the synthesis of neonicotinoids. Russian Journal of Organic Chemistry, 40: 1709-1726. doi: 10.1007/s11178-005-0089-y

Luty, S., Latuszynska, J., Halliop, J., Tochman, A., Obuchowska, D., Przylepa, E. \& Korczak. E. (1998). Toxicity of dermally applied alpha-cypermethrin in rats. Annals of Agricultural and Environmental Medicine, 5: 109-115.

Luty, S., Latuszynska, J., Obuchowska-Przebirowska, D., Tokarska, M. \& Haratym-Maj, A. (2000). Subacute toxicity of orally applied alphacypermethrin in swiss mice. Annals of Agricultural and Environmental Medicine, 7: 33-41. gonionotus, and $4.5 \mu \mathrm{gl}-1$ in Cyprinus carpio carpio, respectively (Grayson et al., 1990; Yılmaz et al., 2004). In this study, $\mathrm{LC}_{50}$ was calculated as $15.62 \mu \mathrm{gl}-1$ for the tadpoles of $B$. variabilis following alpha-cypermethrin exposure for 96 hours. The toxic tolerance of the tadpoles of $B$. variabilis to alphacypermethrin is thought to be higher than that of the other species mentioned. The fact that this detected value was first calculated for the species concerned is thought to contribute to the literature.

Paulov, S. (1990). Potential impact of pyrethroids (cypermethrin) on the model amphibians (Rana temporaria). Biologia (Bratislava), 45: 133-139.

Polat, H., Erkoç, F.Ü., Viran, R. \& Koçak, O. (2002). Investigation of acute toxicity of beta-cypermethrin on guppies Poecilia reticulata. Chemosphere, 49: 39-44. doi:10.1016/S0045-6535(02)00171-6

OECD (2008). The Amphibian Metamorphosis Assay. Guideline for the Testing of Chemicals. Organisation for Economic Co-operation and Development. $33 \mathrm{pp}$.

Saha, S. \& Khaviraj, A. (2008). Acute toxicity of synthetic pyrethroid cypermethrin to some freshwater organisms. Bulletin of Environmental Contamination and Toxicology, 80: 49-52. doi: 10.1007/s00128-007-9314-4

Sarıkaya, R. (2009). Investigation of acute toxicity of alpha-cypermethrin on adult nile tilapia (Oreochromis niloticus L.). Turkish Journal of Fisheries and Aquatic Sciences, 9: 85-89.

Solomon, K.R., Giddings, J.M. \& Maund, S.J. (2001). Probabilistic risk assessment of cotton pyrethroids: I. Distributional analyses of laboratory aquatic toxicity data. Environmental Toxicology and Chemistry, 20: 652659. doi: $10.1002 /$ etc. 5620200326

Stöck, M., Moritz, C., Hickerson, M., Frynta, D., Dujsebayeva, T., Eremchenko, V., Macey, J.R., Papenfuss, T.J. \& Wake, D.B. (2006). Evolution of mitochondrial relationships and biogeography of palearctic toads (Bufo viridis subgroup) with insights in their genomic plasticity. Molecular Phylogenetics and Evolution, 41: 663-689. doi:10.1016/j.ympev.2006.05.026

Turabi, M.S. (2007). The Licensing of Plant Protection Products (In Turkish) Paper presented at: Pesticides Convention and Exhibition Proceedings, 25-26 October, Ankara, Turkey.

Tyler, M.J. (1998). Australian frogs: A Natural History. Cornell University Press, 1-192.

Wells, K.D. (2007). The ecology and behaviour of amphibians. The University of Chicago Press Chicago. 1085 pp.

WHO (2006). Who specifications and evaluations for public health pesticides. Alpha-cypermethrin. World Health Organization. 34 pp.

Yılmaz, M., Gül, A. \& Erbaşlı, K. (2004). Acute toxicity of alpha-cypermethrin to guppy (Poecilia reticulata, Pallas, 1859). Chemosphere, 56: 381-385. doi:10.1016/j.chemosphere.2004.02.034

Yu-Tao, T., Zhao-Wei, L., Yang, Y., Zhuo, Y. \& Tao, Z. (2009). Effect of alphacypermethrin and theta-cypermethrin on delayed rectifier potassium currents in rat hippocampal neurons. Neurotoxicology, 30: 269-273. doi:10.1016/j.neuro.2009.01.001

Yu, S., Wages, M.R., Cai, Q., Maul, J.D. \& Cobb, G.P. (2013). Lethal and sublethal effects of three insecticides on two developmental stages of Xenopus laevis and comparison with other amphibians. Environmental Toxicology and Chemistry, 32: 2056-2064. doi: 10.1002/etc.2280 